\title{
PENGEMBANGAN BAHAN AJAR MATA KULIAH PENGEMBANGAN MEDIA PEMBELAJARAN MENGGUNAKAN MACRO MEDIA FLASH PROFESSIONAL 8
}

\author{
Heni Purwati'), Aryo Andri Nugroho'), Lilik Ariyanto ${ }^{3)}$, Ahmad Nashir Tsalatsa ${ }^{4}$ \\ ${ }^{1}$ FPMIPATI, Universitas PGRI Semarang \\ email: henimat2016@gmail.com \\ ${ }^{2}$ FPMIPATI, Universitas PGRI Semarang \\ email: ndrie024mp@gmail.com \\ ${ }^{3}$ FPMIPATI, Universitas PGRI Semarang \\ email: ariyanto.lilik144@gmail.com \\ ${ }^{4}$ FPMIPATI, Universitas PGRI Semarang \\ email: nashir.indonesia@gmail.com
}

\begin{abstract}
The research objective is to produce a module by using a Macromedia Flash both content and presentation material, which is able to contribute comprehension of concept of students in the subject of development of instructional media.

This refers to the development of research Thiagarajan there are four phases, definition (define), design (design), development (develop), and dissemination (dessiminate). The development phase of module of the 4-D (Four D Device) Thiagarajan Semmel and Semmel to design a module on the course development of instructional media. The process of developing this module starts from the stage of defining or analysis. The process of designing a module that was developed based on information obtained from the analysis phase of the open-ended, students, materials, tasks that support and then do the design stage or the design. And then the last stage is the stage of development. Development of modules on the course development of instructional media developed proven valid content with the results of assessment for an average of $85.5 \%$. The results are based on votes of validator to provides good value and can be used with minimal revision.
\end{abstract}

Keywords: development, module, macromedia flash

\section{PENDAHULUAN}

Pembelajaran

matematika bertujuan

pendidikan

menyiapkan

mahasiswa untuk menyelesaikan masalah

sehari-hari dengan melibatkan mahasiswa

dalam beraktifitas pengumpulan data,

ekplorasi, interpretasi, reasoning,

mendesain model, penganalisaan,

memformulasikan

hipotesis,

menggeneralisasi dan memeriksa outcome.

Dengan demikian, disamping untuk

mencapai tujuan konten pembelajaran tersebut, para mahasiswa perlu dibekali pula dengan kemampuan-kemampuan tertentu terutama kemampuan animasi multimedia sehingga mampu mengembangkan dan membuat suatu media pembelajaran yang layak.

Salah satu tinjauan yang sangat penting dalam pembelajaran matematika adalah perlunya suatu pembelajaran matematika yang menekankan pembelajaran menyenangkan dan proses kreativitas untuk meningkatkan 
pemahaman konsep mahasiswa. Salah satu upaya yang telah dilakukan pemerintah untuk meningkatkan pendidikan di Indonesia adalah dengan menyempurnakan kurikulum di semua jenjang pendidikan sehingga akan menciptakan pembelajaran yang efektif. Menurut Guskey (1982), pembelajaran yang efektif ditandai dengan adanya ketercapaian ketuntasan dalam pemahaman konsep, adanya pengaruh yang positif antara variabel bebas dengan variabel terikat, adanya perbedaan prestasi antara kelas eksperimen dengan kelas kontrol.

Berdasarkan observasi dalam pembelajaran mata kuliah pengembangan media pembelajaran, bahan ajar dalam pembelajaran yang digunakan tidak mengembangkan potensi mahasiswa dengan maksimal sehingga pemahaman konsepnya tidak optimal karena belum mempunyai bahan ajar sendiri sesuai dengan karakteristik mahasiswa Universitas PGRI Semarang (UPGRIS). Pengembangan media pembelajaran diperlukan oleh para calon guru dalam dunia kerja yang sesungguhnya, karena pemilihan media pembelajaran tidak dapat disamaratakan di seluruh sekolah, karena kontekstualitas, kemampuan mahasiswa, sarana pendukung dan lingkungan sekolah yang berbeda-beda.
Penelitian-penelitian yang telah dilakukan di UPGRIS menyimpulkan bahwa pada pembelajaran berbasis ICT yang telah dilaksanakan memberikan dampak yang baik yaitu dapat menuntaskan hasil belajar peserta didik dan menumbuhkan keaktifan peserta didik (Prayito, 2011). Sebelumnya, Ariyanto (2011) juga melakukan penelitian pada materi Geometri, menyimpulkan bahwa pembelajaran Geometri menggunakan multimedia seperti video pembelajaran efektif dapat meningkatkan aktivitas dan motivasi belajar mahasiswa. Nugroho (2013) dalam pengembangan bahan ajar Analitic Geometry II yang bermanfaat bagi mahasiswa dalam pembelajaran

Penelitian yang sudah terlaksana di luar UPGRIS juga menyimpulkan secara mayoritas pembelajaran mengunakan $e$ learning baik. Hasil penelitian Rosenberg (dalam Isjoni dkk 2008:9) menyatakan bahwa e-learning yang menggunakan teknologi internet dalam mengirimkan serangkaian solusi dapat meningkatkan pengetahuan dan keterampilan pesera didik. Hal ini dapat dilakukan dengan mengintegrasikan tekhnologi ke dalam ilmu pengetahuan dan matematika.

Beradasarkan uraian tersebut, maka peneliti merumuskan masalah yang menjadi fokus penelitian, antara lain bahan ajar pada mata kuliah pengembangan media pembelajaran seperti apa yang 
sesuai dan layak digunakan di lingkungan Universitas PGRI Semarang.

\section{METODE PENELITIAN}

\section{a. Pendekatan Penelitian}

Prosedur pengembangan dalam penelitian ini, mengacu pada pengembangan 4D Thiagarajan. Pengembangan ini terdiri dari 4 tahap yaitu pendefinisian (define), perancangan (design), pengembangan (develop), dan penyebaran (dessiminate). Dalam penelitian ini dibatasi sampai pengembangan (develop).

\section{1) Tahap pendefenisian (define)}

Tujuan dari tahap ini adalah untuk menetapkan dan menentukan syarat-syarat pembelajaran yang meliputi tujuan pembelajaran dan batasan materi pembelajaran. Adapun langkah-langkah dalam tahap ini adalah sebagai berikut.

a) Analisis awal-akhir

Langkah pertama dalam tahap pendefenisian (define) adalah melakukan analisis awal-akhir. Dalam penelitian ini, peneliti akan banyak melakukan pengamatan dan analisis untuk mengetahui bagaimana kondisi proses pembelajaran di kelas tersebut. Hal ini bertujuan untuk memperoleh informasi mengenai masalah mendasar yang perlu diupayakan pemecahannya.

b) Analisis mahasiswa
Analisis mahasiswa dilakukan untuk menelaah tentang karakteristik mahasiswa. Karakteristik mahasiswa yang dimaksud meliputi latar belakang pengetahuan mahasiswa khususnya kemampuan dasar matematik, serta kemampuan dasar pengoperasian komputer. Hasil telaah tersebut digunakan sebagai bahan pertimbangan untuk mengembangkan bahan ajar pada matakuliah pengembangan media pembelajaran.

c) Analisis materi

Pada langkah ini dilakukan kegiatan yaitu mengidentifikasi, merinci, dan menyusun secara sistematis materi-materi utama yang akan dipelajari oleh mahasiswa, selanjutnya materi tersebut disusun secara hirarkis. Materi yang digunakan dalam penelitian ini adalah materi yang berkaitan dengan mata kuliah Pengembangan Media Pembelajaran.

d) Analisis tugas

Analisis tugas dilakukan setelah mengetahui materi yang akan diajarkan sehingga dapat diketahui tugas-tugas yang harus diselesaikan mahasiswa selama pembelajaran dilaksanakan. Analisis tugas juga dapat memudahkan dosen untuk merumuskan tujuan-tujuan khusus yang akan dicapai.

e) Spesifikasi tujuan pembelajaran 
Dari analisis materi dan analisis tugas yang telah dilakukan diharapkan dapat dihasilkan tujuan pembelajaran khusus yang merupakan dasar untuk menyusun tes dan merancang materi pembelajaran. Kegiatan yang dilakukan pada langkah ini adalah merumuskan tujuan-tujuan pembelajaran khusus (indikator pencapaian) berdasarkan analisis materi dan analisis tugas.

\section{2) Tahap perancangan (design)}

Tahap ini bertujuan untuk merancang buku dan instrumen penelitian sehingga diperoleh prototipe (buku, Silabus, RPP dan instrumen penelitian). Kegiatan yang dilaksanakan pada tahap ini terdiri atas tiga kegiatan, yaitu: (1) pemilihan media, (2) pemilihan format dan (3) perencanaan awal konsep bahan ajar. Secara singkat masing-masing kegiatan pada tahap ini dijelaskan sebagai berikut.

a) Pemilihan media

Kegiatan ini dilakukan untuk menentukan buku dan alat pembelajaran yang tepat untuk digunakan dalam pelaksanaan pembelajaran. Proses pemilihan media ini disesuaikan dengan hasil analisis tugas, analisis materi dan analisis mahasiswa. Selain itu, media yang dipilih harus disesuaikan dengan karakteristik mahasiswa dan fasislitas yang tersedia atau yang dapat

disediakan di kampus.

b) Pemilihan format

Kegiatan pada tahap ini meliputi pemilihan format untuk mendesain atau merancang isi pembelajaran, pemilihan strategi, pendekatan, metode pembelajaran dan sumber belajar.

c) Perancangan awal

Kegiatan yang dilaksanakan dalam tahap ini adalah merancang bahan ajar matakuliah Pengembangan Media Pembelajaran .

\section{3) Tahap pengembangan (develop)}

Tujuan dari tahap ini adalah untuk menghasilkan draf buku pembelajaran dan perangkat pembelajaran yang telah direvisi berdasarkan masukan para ahli dan data yang diperoleh dari hasil uji keterbacaan. Kegiatan yang akan dilakukan pada tahap ini adalah penilaian ahli, uji keterbacaan. Secara singkat masing-masing kegiatan pada tahap ini dijelaskan sebagai berikut.

a) Validasi ahli

Setelah semua perangkat pembelajaran draft awal selesai, pada tahap perancangan selanjutnya dilakukan penilaian (divalidasi) oleh beberapa orang yang dipandang ahli (expert judgment). Yang dimaksud ahli dalam hal ini adalah para validator yang berkompeten untuk melakukan penilaian terhadap buku pembelajaran 
dan perangkat pembelajaran. Saran dari para validator digunakan sebagai bahan untuk melakukan revisi buku pembelajaran dan perangkat pembelajaran hasil pengembangan yang dilakukan pada tahap perancangan (draft awal).

\section{b. Metode atau prosedur pengumpulan} data

Data yang akan dikumpulkan pada penelitian ini adalah data validasi ahli terhadap desain buku pembelajaran dan perangkat pembelajaran. Data validasi desain buku pembelajaran dan perangkat pembelajaran diambil dengan metode expert judgement dan focus group discussion (FGD). Instrumen yang digunakan untuk mengambil data validasi desain buku pembelajaran dan perangkat pembelajaran adalah lembar validasi, lembar catatan diskusi dan lembar angket uji keterbacaan.

\section{HASIL DAN PEMBAHASAN}

\section{a. Hasil Penelitian}

Dari penelitian yang telah dilaksanakan, baik dari persiapan, pembuatan modul, instrumen dan validasi, maka diperoleh hasil sebagai berikut.

\section{1) Proses Pengembangan Modul Hingga Mencapai Valid}

Pada bagian ini akan dipaparkan tahapan pada pengembangan modul dengan menggunakan modifikasi teori Thiagarajan (1974).

\section{a) Tahap Pendefinisian}

1) Analisis awal-akhir

Pembelajaran mata kuliah pengembangan media pembelajaran, bahan ajar dalam pembelajaran yang digunakan tidak mengembangkan potensi mahasiswa dengan maksimal sehingga pemahaman konsepnya tidak optimal karena belum mempunyai bahan ajar sendiri sesuai dengan karakteristik mahasiswa Universitas PGRI Semarang (UPGRIS). Untuk mencakup semua pembelajaran diatas maka dibutuhkan bahan ajar atau modul yang tepat yaitu pembelajaran yang memanfaatkan teknologi namun juga kreatif, mandiri dan bertanggung jawab.

\section{2) Analisis Mahasiswa}

Dengan metode dokumentasi dan studi pustaka diperoleh hasil analisis mahasiswa bahwa mereka rata-rata sudah memiliki laptop. Pengetahuan yang mahasiswa miliki sebelumnya tidak mengarahkan mahasiswanya pada materi yang bersifat menemukan sehingga keikutsertaan mahasiswa dalam pembelajaran masih kurang, dan juga masih kurangnya penggunaan 
bahan ajar pada mata kuliah pengembangan media pembelajaran.

3) Analisis Materi

Berdasarkan diskusi dengan tim dosen pengembangan media pembelajaran terdapat materi yang dapat melibatkan mahasiswa dalam pembelajaran yang konsepnya telah didapatkan mahasiswa melalui konsep-konsep yang telah diterima oleh mahasiswa.

4) Analisis Tugas

Analisis tugas dilakukan setelah mengetahui materi yang akan diajarkan sehingga dapat diketahui tugas-tugas yang harus diselesaikan mahasiswa selama pembelajaran dilaksanakan.

5) Spesifikasi tujuan pembelajaran

Dari analisis materi dan analisis tugas yang telah dilakukan diharapkan dapat dihasilkan tujuan pembelajaran khusus yang merupakan dasar untuk menyusun tes dan merancang materi pembelajaran.

\section{b) Tahap Perancangan}

Setelah dilakukan analisis pada tahap pendefinisian, maka disusun modul.

\section{1) Pemilihan Media}

Berdasarkan hasil analisis awalakhir dan lingkungan dipilih untuk membuat modul. Modul dibuat khusus dengan memperhatikan langkah- langkah pembelajaran sehingga tetap memungkinkan mahasiswa mengeksplor kemampuan yang mereka miliki.

2) Pemilihan format

Kegiatan pada tahap ini meliputi pemilihan format untuk mendesain atau merancang isi pembelajaran, pemilihan strategi, pendekatan, metode pembelajaran dan sumber belajar.

3) Perancang Awal

Kegiatan ini merupakan perencanaan membuat modul pengembangan media pembelajaran menggunakan macromedia flash.

\section{c) Tahap Pengembangan}

Penilaian ahli meliputi validasi produk, yaitu mencakup semua modul pembelajaran yang dikembangkan pada tahap perancangan. Hasil dari revisi berdasarkan penilaian validator menghasilkan draft II. Untuk penelitian ini kita batasi sampai validasi ahli dan belum sampai uji coba terbatas

\section{b. Hasil Validasi dan Uji Keterbacaan Media Pembelajaran}

Berdasarkan hasil validasi ahli dan uji keterbacaan terhadap media pembelajaran diperoleh hasil validasi dan uji keterbacaan modul pengembangan media pembelajaran beserta materinya yang dirancang baik. Dengan demikian 
dihasilkan modul yang sesuai dengan kriteria yang ditentukan/ valid. Rata-rata nilai dari kedua validator yaitu $85,5 \%$.

\section{1) Validator Pertama}

Validator pertama yaitu Dewi Wulandari, M.Si menyatakan modul baik dan dapat digunakan dengan revisi sedikit dengan nilai rata-rata $85,5 \%$. Berdasarkan hasil validasi ahli, beberapa revisi yang dilakukan dapat dilihat pada Tabel 1.

Tabel 1. Revisi Modul Berdasarkan Masukan dari Validator Pertama

\begin{tabular}{|c|c|c|}
\hline & $\begin{array}{c}\text { Modul } \\
\text { Sebelum } \\
\text { Revisi }\end{array}$ & $\begin{array}{c}\text { Modul Sesudah } \\
\text { Revisi }\end{array}$ \\
\hline a) & Belum ada & a) Daftar isi sudah \\
\hline b) & Capture & b) Capture sudah \\
\hline & yang & diganti dengan \\
\hline & disertakan & yang lebih jelas \\
\hline & kurang jelas & c) Latihan soal \\
\hline c) & Latihan soal & sudah \\
\hline & belum & disertakan pada \\
\hline & semuanya & setiap bab \\
\hline & $\begin{array}{l}\text { ada pada } \\
\text { setiap bab }\end{array}$ & \\
\hline
\end{tabular}

\section{2) Validator Kedua}

Validator kedua yaitu Aurora Nur Aini, M.Si menyatakan baik dan dapat digunakan dengan revisi sedikit. Rata-rata penilaian validator yaitu $85,5 \%$. Berdasarkan hasil validasi ahli, beberapa revisi yang dilakukan dapat dilihat pada Tabel 2.
Tabel 2. Revisi Modul Berdasarkan Masukan dari Validator kedua

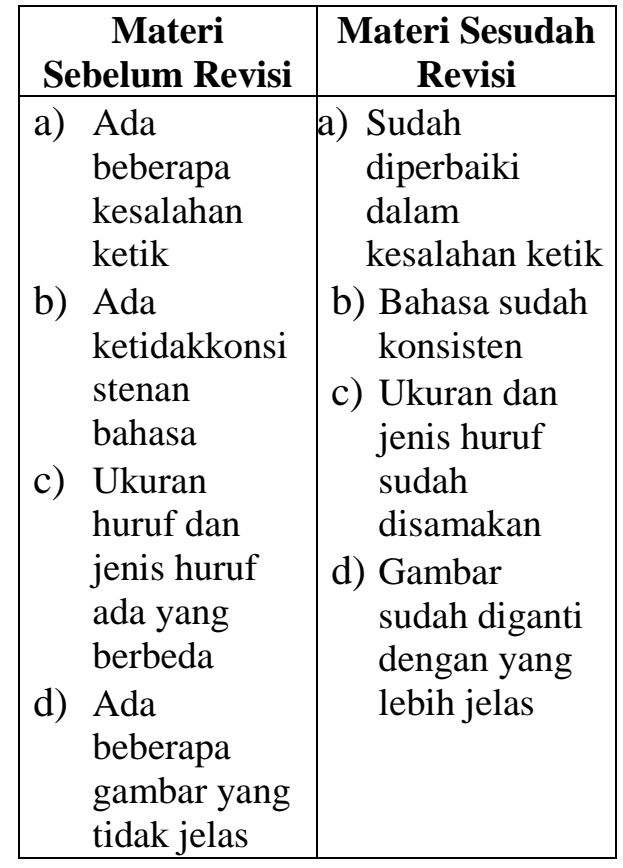

\section{3) Hasil Uji Keterbacaan}

Berdasarkan hasil uji keterbacaan pada lembar angket respon mahasiswa terhadap keterbacaan bahan ajar mata kuliah pengembangan media pembelajaran menggunakan macromedia flash profesional 8 mendapat respon yang baik dan ada beberapa yang perlu diperbaiki dari segi keterbacaanya. Beberapa yang mendapat perhatian untuk diperbaiki diantaranya langkah-langkah kurang jelas serta latihannya juga kurang jelas.

\section{c. Pembahasan}

1) Proses Pengembangan Modul Hingga Mencapai Valid

Proses pengembangan modul mata kuliah pengembangan media pembelajaran 
dengan menggunakan teori thiagarajan melalui beberapa tahap meliputi (1) tahap pendefinisian, (2) tahap perancangan dan (3) tahap pengembangan.

Pada tahap pendefinisian akan menetapkan dan menentukan syarat-syarat pembelajaran yang meliputi tujuan pembelajaran dan batasan materi pembelajaran. Dalam penentuannya memperhatikan analisis awal-akhir, analisis mahasiswa, analisis materi, analisis tugas dan spesifikasi tujuan pembelajaran.

Pada tahap perancangan bertujuan untuk merancang modul mata kuliah pengembangan media pembelajaran dan instrumen penelitian sehingga diperoleh prototipe. Dalam perancangannya peneliti konsultasi dengan ahli dalam pembuatannya sehingga dapat merancang dan mendesain modul pembelajarannya. Kegiatan yang dilaksanakan pada tahap ini, yaitu: (1) pemilihan media, (2) pemilihan format dan (3) perencanaan awal modul matakuliah pengembangan media pembelajaran.

Pada tahap pengembangan menghasilkan draft modul matakuliah pengembangan media pembelajaran. Kegiatan yang dilakukan pada tahap ini adalah penilaian ahli dan uji keterbacaan. Modul pembelajaran yang sudah dirancang divalidasi oleh ahli untuk mendapatkan masukan dan saran selain itu juga dilakukan uji keterbacaan dari sisi kalimat dan bahasa.

\section{2) Pembahasan Hasil Modul Pengembangan Media Pembelajaran}

Berdasarkan hasil validasi para ahli mengatakan modul yang dirancang sudah bagus, inovatif, dan menyenangkan. Saat FGD disarankan modul pembelajarannya bisa digunakan oleh mahasiswa dengan baik. modul pembelajaran yang dirancang mudah digunakan dan mudah dipelajari. Materi pembelajaran yang dirancang sesuai dengan hasil diskusi rumpun mata kuliah media pengembangan pembelajaran. Materi dirancang dengan latihannya berupa soal yang nantinya mahasiswa diminta mengerjakan secara praktek di komputer masing-masing. Penilaian validator rata-rata baik dan dapat digunakan dengan sedikit revisi. Materi pembelajaran sudah layak digunakan di lapangan dan harapannya saat diujicobakan mendapat antusias yang baik oleh mahasiswa dan dosen sehingga dapat meningkatkan prestasi belajar mahasiswa. Berdasarkan uji keterbacaan modul pengembangan media pembelajaran sudah baik karena sebelumnya belum ada modulnya dalam pembelajaran, namun ada beberapa yang perlu di perbaiki meliputi langkah-langkah dan latihan soal yang kurang jelas. Dari hasil uji keterbacaan 
tersebut modul tersebut sudah diperbaiki dan harapannya pada saat uji coba secara terbatas sudah di pahami oleh mahasiswa dengan jelas.

Pada pembelajaran ICT yang telah dilaksanakan memberikan dampak yang baik yaitu dapat menuntaskan hasil belajar peserta didik dan menumbuhkan keaktifan peserta didik (Prayito, 2011). Sebelumnya, Ariyanto (2011) juga melakukan penelitian pada materi Geometri, menyimpulkan bahwa pembelajaran Geometri menggunakan multimedia seperti video pembelajaran efektif dapat meningkatkan aktivitas dan motivasi belajar mahasiswa. Nugroho (2013) dalam pengembangan bahan ajar Analitik Geometry II yang bermanfaat bagi mahasiswa dalam pembelajaran

\section{KESIMPULAN}

\section{a. Kesimpulan}

Dengan menggunakan langkahlangkah yang dikembangkan oleh 4D Thiagarajan bertujuan untuk memperoleh syarat-syarat yang dibutuhkan dalam pembelajaran dengan menganalisis tujuan dan batasan materi kemudian diperoleh draft I yang kemudian divalidasi oleh ahli dan direvisi sehingga menghasilkan draft II. Karena modul pembelajaran yang dikembangkan telah melalui proses validasi yang ditetapkan oleh orang yang ahli/pakar dibidangnya dengan nilai rata- rata $85,5 \%$, maka modul pengembangan media pembelajaran yang dikembangkan dalam penelitian ini valid.

\section{b. Saran}

1) Dalam penelitian ini telah dihasilkan modul pengembangan media pembelajaran. Agar diperoleh modul yang benar-benar baik dan/atau guna menyempurnakan modul pembelajaran yang telah dikembangkan ini, perlu dilakukan uji coba terbatas media pembelajaran ini di kelas.

2) Pengembangan modul pengembangan media pembelajaran hendaknya juga dikembangkan untuk materi lain

\section{REFERENSI}

Ariyanto, Lilik. 2011. Pengembangan Perangkat Pembelajaran Matematika Anchored Instruction Materi Luas Kubus dan Balok Kelas VIII. Jurnal Matematika dan Pendidikan Matematika AKSIOMA volume 2(2), halaman 215-234.

Guskey, dkk. 1982. The Effectiveness Of Mastery Learning Strategies In Indergraduate Education Courses. University of Kentucky.

Isjoni, dkk. 2008. ICT Untuk Sekolah

Unggul. Yogyakarta: Pustaka Pelajar. 
Pengembangan Bahan Ajar Mata Kuliah Pengembangan Media Pembelajaran Menggunakan Macro Media Flash Professional 8

Heni Purwati, Aryo Andri Nugroho, Lilik Ariyanto, Ahmad Nashir Tsalatsa

------------. 2008. Pembelajaran Terkini.

Yogyakarta: Pustaka Pelajar.

Nugroho, A.N., dkk. 2013. Keefektifan

Pembelajaran Matematika Berbasis

Micruled Berbantuan E-Learning

Pada Mata Kuliah Matematika

SMP. Penelitian tidak

dipublikasikan.

Prayito.2011. Pengembangan Perangkat

Pembelajaran Matematika

Humanistik Berbasis

Konstruktivisme Berbantuan ICT

Materi Segitiga Kelas VII. Jurnal

Matematika dan Pendidikan

Matematika AKSIOMA volume 2(2),

halaman187-198.

Thiagarajan,S. Smmel, D.S. Smmel, M.I.

1974. Instruksional Development for

teacher of exceptional Children.

Blomington: Indiana University. 